原著論文

\title{
独立小型太陽光発電システムの利用実態と課題 一モンゴルの遊牧民を事例としてー
}

アジヤバト アマルバヤル ${ }^{\left.*_{1}\right)}$ ・ 中島正裕 ${ }^{2)} \cdot$ 大谷謙仁 $^{3)}$ ・黑川浩助 ${ }^{1)}$

1)東京農工大学工学部 $\overline{\mathbf{T}} 184-8588$ 東京都小金井市中町 2-24-16

2)東京農工大学農学部 $\bar{T}$ 183-8509 東京都府中市幸町 3-5-8

3)産業技術総合研究所電力エネルギー研究部門 テ $305-8568$ つくば市梅園 1-1-1

\section{要旨}

モンゴル国では，遊牧民の生活水準の向上を目的として住居（ゲル）を電化するために 1999 年から独立小型太陽光発電システム（SHS）が導入されている. 本研究では, ヒアリン グ調査（67 世帯）とアンケート調查（359 票）により SHS 利用者の利用実態と未利用者の認 識を明らかにし, 今後のSHSの普及定着に向けての課題について検討した。主な知見とし て, 以下の $5 つ か ゙$ 得られた.

（1）SHSの導入によって照明とテレビの使用が可能になったことに対して，SHS 利用者は 高い満足感を得ていた。 また, SHS は小型かつ軽量であり, 燃料を必要としないため, 他の 電源と比較して, 移動を繰り返す遊牧民のライフスタイルに適合する技術であることが示 された.（2）SHSを導入した世帯の 78\%が「10 万ソーラーゲル計画」による補助金と無利 子ローンを活用しており, 市場を通しての普及が進んでいない，(3) SHSの課題は, SHSの 保証期間が 1 年以内と短いこと, 修理店または技術者が近くの村落センターまたは県都に いないことなどである。(4) 未利用者の SHSに対する認識度が高く, SHS を購入予定がある という回答者が多いことが分かった。（5）SHSの普及定着及びそれによる遊牧民の農牧業の 生産性向上のための課題は, 市場原理に向けた優遇措置の見直し, サポート体制の整備, 農牧業情報の活用環境の整備である。

キーワード

電化, 独立小型の太陽光発電システム, アンケート調查, 利用実態, 遊牧民世帯

はじめに

モンゴル国では農牧業が GDPの約 $20 \%$ を占め る基幹産業であり,その内 8 割は遊牧民世帯が営 む家畜業（以降，遊牧業とする）である（NSO 2004)。しかし，1991年の市場経済化以降，遊牧 民世帯と家畜頭数の増加, 都市と幹線道路の周辺 地域における家畜の集中, さらには気候変動の影 響による砂漠化など遊牧業を営む上で様々な問題 が起きている.これらの社会的及び自然的要因に

* Corresponding Author

E-mail: amar@cc.tuat.ac.jp
よって,牧草地の筧廃が生じており（鈴木 2003）， 遊牧業の生産性が低下している. 遊牧業の生産性 とリスク管理の能力を向上させるために, 遊牧業 の伝統的な知恵の伝承と実践的スキルなどに関す る農牧業情報の共有は重要な課題である。

こうした状況下，1996年には遊牧民のラジオ 放送スタジオが3ヶ所に整備されており, 遊牧民 の能力開発と情報共有のために放送活動が行われ ている (Robinson 1997). また, 最新の科学的手 法や技術導入が検討され, リモートセンシング技 術を牧草管理に活用する実用的な研究開発が進め 
られ（Erdenesaikhan 2002），情報配信システムと 体制が提案されている（Tserendash 2000）。本多 (1999)はモンゴル国において, 人工衛星データを 利用するリモートセンシング技術を活用して, 地 上の植物の分布状況と生産量や質 (生育状況)を 把握する手法を開発した。このように, 遊牧業の 生:産性の局上と自然災害の回避に最新技術を駆使 した高度情報の活用が期待されている。

遊牧民世帯は,こうした農牧業に関する高度な 情報や日常的に得る天気予報, 市場情報, 教育情 報などの入手と交換のためにはラジオやテレビ放 送や短波通信機器が必要であり,電化が不可欠で ある.しかし，モンゴル全国における遊牧民世帯 の電化率は, 年々上昇傾向にあるものの 2003 年に おいてわずか $16.8 \%$ である（表 1 ）。遊牧民は，広 く薄く分布する牧草資源を求めて移動を繰り返し ているため,携帯性の良い独立電源システムが必 要である.帮際に利用されている独立電源システ ムの種類とそれぞれの特徴比較を表 2 に示す. 安 定的に高出力が得られる小型ガソリン発電機は古 くから使用されているが,遠隔地では燃料の安定 的な調達と貯蔵, 運搬費が問題になるため, 広く
普及してないのが現状である.また, 安価で携带 性が良い小型風力発電システムは, 風力資源が局 所的で風速や風向の変動が大きく（Nikolakaki 2001), 冬営地などは風を直接受けない場所が選 ばれるなどの理盺があり, 全国に約3千台しか使 用されてない(ADB 2002).

このような中, 日射量が豊富なモンゴルで は, 遊牧民の住居（ゲル）を電化するために独 立小型太陽光発電システム淑) (SHS : ソーラー ホームシステム, 図1)が注目されており, 国家 プロジェクト(「10万户ソーラーゲル計画」) と して，2005年 4 月時点で約 3 万 2 千戸に SHS が 導入されている.

筆者らは, 乾燥・半乾燥地域における遊牧民世: 帯及び集落へ太陽光発電システムを導入する場合 の地域適合性を検証するために,ケーススタディ としてモンゴル国における太陽エネルギー資源の ポテンシャル評価と太陽電池モジュールの暴露試 験と性能評価（Amarbayar et al. 2004）, SHS の運 転データの分析と損失分離を行っている(アジヤ バトアマルバヤル・黒川浩助 2005). 今後, モ ンゴル国におけるSHSのさらなる普及定着のた

表 1 モンゴル全国における遊牧民世帯の生活水準指標の推移(NSO 2004b)

\begin{tabular}{|l|r|r|r|r|}
\hline \multicolumn{1}{|c|}{ 統計指標 } & \multicolumn{1}{c|}{2000} & \multicolumn{1}{c|}{2001} & \multicolumn{1}{c|}{2002} & \multicolumn{1}{c|}{2003} \\
\hline 遊牧民世帯数 & 191,526 & 185,546 & 175,911 & 172,412 \\
\hline 電化率 [\%] & 10.7 & 13.4 & 13.7 & 16.8 \\
\hline TV 所有率 [\%] & 12.8 & 15.7 & 16.7 & 19.3 \\
\hline 自動車所有率 [\%] & 8.7 & 9.5 & 10.5 & 11.5 \\
\hline バイク所有率 [\%] & 16.6 & 18.3 & 18.5 & 19.4 \\
\hline
\end{tabular}

表 2 遊牧民世帯の利用に対する独立小型電源システムの特徽比較

\begin{tabular}{|c|c|c|}
\hline 電源の種類 & 利点 & 弱点 \\
\hline $\begin{array}{l}\text { 独立小型太陽光 } \\
\text { 発電システム } \\
\text { (SHS) }\end{array}$ & $\begin{array}{l}\text { 高い携帯性, 設置と保守管理が簡易, } \\
\text { 維持管理費・低コスト, 無騒音, 燃料 } \\
\text { 不要, 太陽電池の寿命 } 20 \text { 年 }\end{array}$ & $\begin{array}{l}\text { 初期コストが高価, 時間帯と天侯 } \\
\text { による出㫼限, 蓄電池交換 }\end{array}$ \\
\hline $\begin{array}{l}\text { 小型ガソリン発 } \\
\text { 電機 }\end{array}$ & 高出力, 安定的電打供給 & $\begin{array}{l}\text { 燃料とその運搬費が高コスト, 燃 } \\
\text { 料の安定的調達と貯蔵が困難, 騒 } \\
\text { 音, 排気ガス }\end{array}$ \\
\hline $\begin{array}{l}\text { 独立小型風力発 } \\
\text { 電システム }\end{array}$ & $\begin{array}{l}\text { 安価, 高い携帯性, 設置容易, 燃料不 } \\
\text { 要 }\end{array}$ & $\begin{array}{l}\text { 風力資源は局所的, 強風下での危 } \\
\text { 険性, 騒音, 短寿命, 蓄電池交 } \\
\text { 換, 保守管理が必要 }\end{array}$ \\
\hline
\end{tabular}


めには,こうした技術的側面からのアプローチの みならず, SHSの利用者及び未利用者への意識調 查を行い, それらの結果を今後のSHSに関する技 術開発や施策に反映するための知見を得ることが 必要である.また，世界的にみても，SHS は開発 及び発展途上国を中心に 2000 年まで約 130 万台が 導入されているが, SHSのフィールドモニタリン グやSHSユーザの声を聞くことがほとんど行われ ておらず，SHSの利用実態が未解明である (Nieuwenhout ら (2001).

そこで本研究では, SHSを利用している遊牧民 の利用実態 (導入動機, 満足度, 利用形態, ニー ズや問題点等) と未利用者のSHSに対する導入の 可能性を明らかにし, 今後のSHSの普及定着に向 けての課題について検討する.

\section{調查・分析方法}

本研究のアンケート調査対象者は, モンゴル国 の西部, 中部, 南部の地域から6つの県 (ホブド 県, ザブハン県, ブルガン県, ドンドゴビ県, ド ルノゴビ県, ヘンティー県) の遊牧民世帯とした (図2).

SHSの利用実態のアンケート項目の作成にあ たっては, 文献調查（新エネルギー財団 2005） 及びドルノゴビ県サインシャンド村落（11 世 帯) とヘンティー県ダダル村落 (12世帯) の遊 牧民に現地で予備調查（ヒアリング調查）を行 い, SHS利用者に対して表3に示すようにSHSの 導入の動機, SHSの故障や修理など6つのカテゴ リーからなる20項目の質問を設定した. 実施方

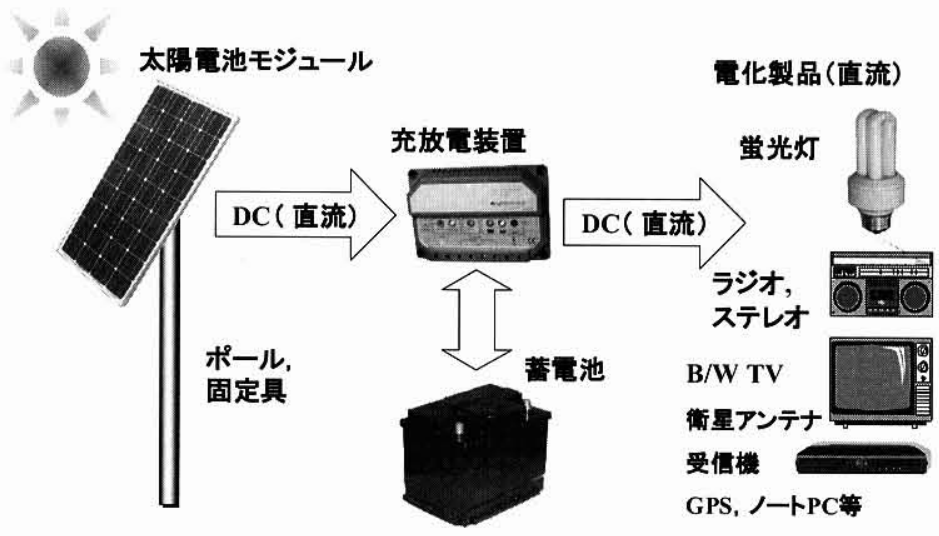

図1 独立小型の太陽光発電システム (SHS)の構成

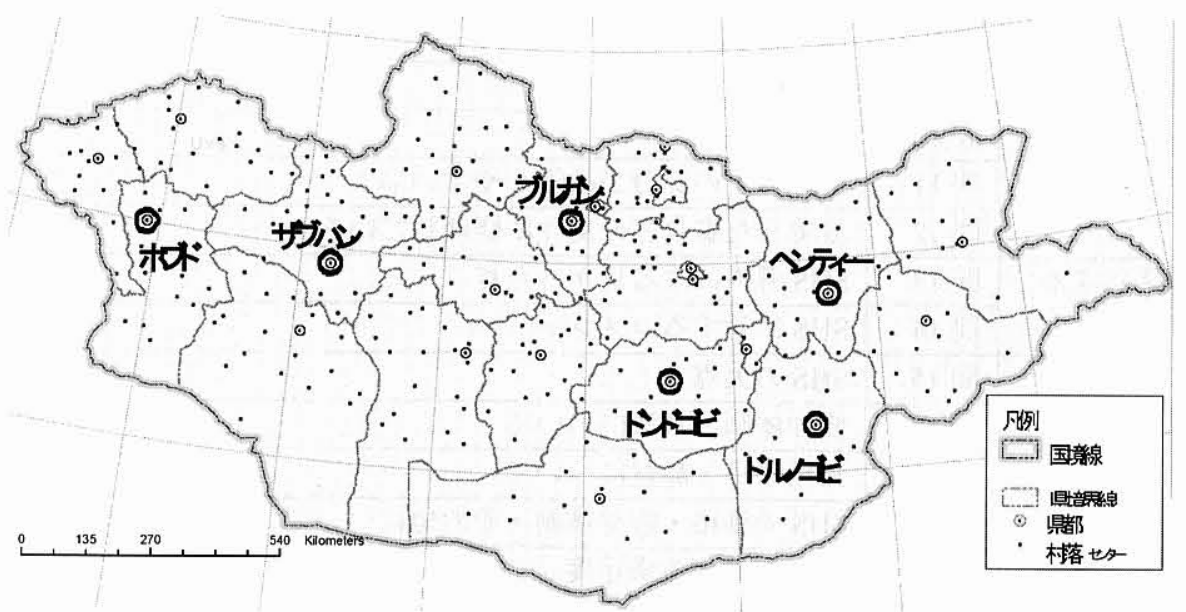

図2 調查対象地域の位置 
法は，モンゴル国「燃料エネルギー省」の協力を 得て, 調查協力の得られた 5 県 (ホブド県, ザブ ハン県, ブルガン県, ドンドゴビ県, ドルノゴビ 県）の村落センターに合計 3000 部の調查票を郵 送し（2005年6月 21 日）, 各村落センターを訪れ た遊牧民の中で，SHS を所有する遊牧民に調查 票が配布された。

アンケート実施の結果, 359部（表5）が回収さ れ，回収率は約 $12 \%$ あっあた.アンケート調查の 回収率として $12 \%$ は低いが, 牧草地を求めて移動 し住所が不確定などの特殊条件を有する遊牧民が 対象者であること, 調査に要する費用と時間が掛 かること,さらには, 既述したようにSHSの利用 形態が未解明であることを考虑すると，359部で もSHSに対する利用者意識の傾向をみることは意 義があると考えられる。しかしながら，アンケー 卜調査からはSHSの利用実態の傾向を概括的には 把握できるものの, 使用しているSHSの性能（定 格出力) 別にみた利用実態の相違や発電量と消費
電力量のバランスなどについては具体的に把握で きない，そこで，この点を明らかにするために， 代表的な定格出力の SHS $(62 \mathrm{~W}, 50 \mathrm{~W}, 20 \mathrm{~W}) を$ それぞれ所有する3世带の遊牧民のヒアリング調 查結果を詳細に示す.

また, 今後のSHSの導入の可能性を検討するた め, SHS未利用者に対してSHSの認識程度や今後 の購入予定など $7 つ の$ 項目を設定した(表4). 実 施方法は, ブルガン県ヒシグウンドル村落 (37世

表4SHS未利用者に対するアンケート調査の質 問項目

\begin{tabular}{|c|c|c|}
\hline 設問分類 & 設問 & 質問内容 \\
\hline \multirow{3}{*}{$\begin{array}{l}\text { アンケート } \\
\text { 回答者の属 } \\
\text { 性 }\end{array}$} & 問 1 & 回答者の家族数 \\
\hline & 問 2 & 年間の可均収入 \\
\hline & 問 3 & 家畜所有頭数 \\
\hline \multirow{2}{*}{$\begin{array}{l}\text { SHS の認識 } \\
\text { 程度 }\end{array}$} & 問 4 & SHS に対する認識程度 \\
\hline & 問 5 & SHS に関するコメント \\
\hline \multirow{2}{*}{$\begin{array}{l}\text { SHS の導入 } \\
\text { 可能性 }\end{array}$} & 問 6 & 電源システムの購入の意思 \\
\hline & 問 7 & 導入したい電源の種類 \\
\hline
\end{tabular}

表3 SHS利用者に対するアンケート調査の質問項目

\begin{tabular}{|c|c|c|}
\hline 設問分類 & 設問 & 質問内容 \\
\hline \multirow{3}{*}{$\begin{array}{l}\text { アンケート回答 } \\
\text { 者の属性 }\end{array}$} & 問 1 & 回答者の家族数 \\
\hline & 問 2 & 年間の平均収入 \\
\hline & 問 3 & 家畜所有頭数 \\
\hline \multirow{5}{*}{$\begin{array}{l}\text { SHS の䆃入, そ } \\
\text { の動機 }\end{array}$} & 問 4 & SHS の購入先 \\
\hline & 問 5 & 使用開始時期 \\
\hline & 問 6 & SHS 導入の動機 \\
\hline & 問 7 & SHS を購入する前にほかの電源を使用していたかどうか \\
\hline & 問 8 & ほかの電源ではなくSHS を選んだ理由 \\
\hline \multirow[t]{4}{*}{ SHS の維持管理 } & 問 9 & 太陽電池の設置場所 \\
\hline & 問 10 & 故障の回数 \\
\hline & 問 11 & SHS のどの部分が故障しやすいか \\
\hline & 問 12 & 故障した場合どのように修理しているか \\
\hline \multirow{2}{*}{$\begin{array}{l}\text { SHS 導入による } \\
\text { 効果・影響 }\end{array}$} & 問 13 & SHS 導入による良かった点 \\
\hline & 問 14 & SHS に対するコメント \\
\hline \multirow{4}{*}{$\begin{array}{l}\text { SHS の欠点, 今 } \\
\text { 後の要望 }\end{array}$} & 問 15 & SHSの欠点 \\
\hline & 問 16 & 修理体制・方法について \\
\hline & 問 17 & 長期保証・品質について \\
\hline & 問 18 & SHS の価格・販売体制・その他について \\
\hline \multirow{2}{*}{$\begin{array}{l}\text { SHS に対する総 } \\
\text { 合的評価 }\end{array}$} & 問 19 & SHS に対する満足度 \\
\hline & 問 20 & 他人への勧め \\
\hline
\end{tabular}


帯)，ドルノゴビ県サインシャンド村落（6世帯） 及びヘンティー県（7世帯）の遊牧民からSHSを 利用していない遊牧民の協力を得て, 合計 50 世帯 （表 5）に対面式アンケート調査を行った.

\section{遊牧民へのSHSの導入経緯}

モンゴル国では, 1989年に11W(定格最大出力) のアモルファスシリコン太陽電池で充電するラン ターン (中国製) が約 $2500 セ ッ ト$ 販売されたこと で注2)，太陽電池が遊牧民に知られるようになっ た. その後, NEDO（1997）はモンゴル国におい て1992年から1996年にかけて携带型の太陽光発 電システムの実証研究を行い, モンゴルの非定住 の社会システムをフィールドにして, 蓄電池やイ ンバータ等の周辺機器を含むSHSの小型軽量化, 可搬性と信頼性の向上を図った。

これらの実証実験より, SHSが遊牧民の生活に 適していることが明らかとなり，モンゴル国政府 は1999年 10 月にモンゴル国会で, 遊牧民の住居 (ゲル)を電化する「10万戸ソーラーゲル計画」を 議決した (Enebish 2000)。この国家プロジェクト は,モンゴル国内約17万戸の無電化遊牧民世帯の 内, 10 万戸に対して2010年までに3つの段階を経 てSHSを普及させるというものである.初段階と して初年度の 2000 年に約 5 干台, 第二段階として $2001 \sim 2005$ 年に約 4 万 5 千台, 第三段階の昖張と 完成期として2006〜2010年には約5万台のSHSを それぞれ導人することを目標としている。

SHSの 1 セット当たりの市場価格は, 太陽電池 モジュール1枚 $(50 \mathrm{~W})$, 蓄電池 $(12 \mathrm{~V}, 75 \mathrm{Ah})$, 充

表 5 対象地域における面接調査と調査票の回収状況

\begin{tabular}{|l|c|c|}
\hline \multirow{2}{*}{ 県名 } & $\begin{array}{c}\text { SHS 利用 } \\
\text { 世帯 }\end{array}$ & $\begin{array}{l}\text { 未利用 } \\
\text { 世帯 }\end{array}$ \\
\cline { 2 - 3 } & $\begin{array}{l}\text { 郵送 } \\
\text { 面接 }\end{array}$ \\
\hline ドルノゴビ & 63 & 6 \\
\hline ドンドゴビ & 27 & - \\
\hline ブルガン & 45 & 37 \\
\hline ヘンティー & - & 7 \\
\hline ホブド & 117 & - \\
\hline ザブハン & 107 & - \\
\hline 合計 & 359 & 50 \\
\hline
\end{tabular}

放電装置等を含めて約 4 万円である. 年間の平均 所得が約 124 万 $\mathrm{Tg}(\mathrm{NSO} 2004)=$ 約 12 万 3 千円 注3）の遊牧民にとってSHSは非常に高額である. このため,「10万戸ソーラーゲル計画」では 1999 年から無利子の1年間ローンを実施し, 2003-2004 年には $50 \%$ の補助金を交付するなどの措置を 行った.モンゴル国「燃料エネルギー省」の推計 では，2000年までに約 900 台，2005年:4月までに 約 3 万 2 千台の SHSが導入されている. 地域別の 導入状況（表 6）をみると, 電化率の低い地域に 対するSHSの導入件数が多い傾向にある.

\section{SHS 利用者へのアンケート調査結果}

\section{アンケート回答者の属性}

SHS 利用世帯の家族数は 4 人 $(28.7 \%)$ または 5 人 $(25.7 \%)$ の割合が多い（表 7 問 1). SHS 利用 世带の収入は 100 万 $\mathrm{Tg}$ (9万4千阴) 以下 $(63.6 \%)$ の割合が多い(表7問2). 農村地域の世帯におけ

表 6 県別遊牧民の世带数, 電化率(2003年) とSHS の導入件数洋 2 ( 2005 年 3 月)

\begin{tabular}{|c|c|c|c|}
\hline 県名 & $\begin{array}{l}\text { 遊牧民 } \\
\text { 世帯数 }\end{array}$ & $\begin{array}{c}\text { 電化率 } \\
{[\%]}\end{array}$ & $\begin{array}{l}\text { SHS } の \\
\text { 導入数 }\end{array}$ \\
\hline アルハンガイ & 17,077 & 6.7 & 2,190 \\
\hline バヤンウルギー & 11,200 & 7.3 & 3,008 \\
\hline バヤンホンゴル & 11,329 & 22.5 & 2,930 \\
\hline ブルガン & 7,268 & 8.8 & 1,055 \\
\hline ヨ゙ビアルタイ & 8,109 & 16.4 & 3,050 \\
\hline ドルノゴビ & 4,092 & 24.7 & 425 \\
\hline ドルノド & 4,803 & 16.0 & 750 \\
\hline ドンドゴビ & 7,955 & 22.6 & 1,215 \\
\hline ザブハン & 10,230 & 8.1 & 2,742 \\
\hline ウブルハンガイ & 17,416 & 20.5 & 2,096 \\
\hline ウムヌゴビ & 6,328 & 34.5 & 820 \\
\hline スフバートル & 7,688 & 21.1 & 2,300 \\
\hline セレング & 2,921 & 30.7 & 409 \\
\hline トゥブ & 8,719 & 16.6 & 383 \\
\hline オブス & 9,920 & 12.9 & 1,550 \\
\hline ホブド & 9,117 & 14.6 & 3,570 \\
\hline ホブスグル & 16,484 & 11.9 & 2,055 \\
\hline ヘンティー & 7,352 & 15.4 & 705 \\
\hline ダルハンウール & 919 & 36.8 & 100 \\
\hline ウラーンバートル & 2,196 & 82.8 & - \\
\hline オルホン & 794 & 43.7 & 150 \\
\hline ヨ゙ビスンベル & 475 & 12.4 & 110 \\
\hline 合計 & 172,392 & 16.7 & 31,613 \\
\hline
\end{tabular}


る全国平均年収が 124 万 $\mathrm{Tg}$ (約 12 万 3 千円社3) あるのに対して (NSO 2004), 本研究のアンケー 卜対象の遊牧民世帯の収入は低い傾向にある.こ の要因は, 農村地域の世帯に現金収入が多い公務 員, 会社員の世帯も含まれるためであると考えら れる.

また, 家畜頭数は遊牧民の資産の主な指標と なっており,一般的には50頭以下の家畜を所有し ている世帯を貧困層, 150-250 頭を所有している 世帯が中間層とされている (Jargal et al. 2004). モ

表7 回答者の属性

\begin{tabular}{|c|c|c|}
\hline 選択項目 & 度数 & [\%] \\
\hline \multicolumn{3}{|l|}{ 問 1 家族数 } \\
\hline 3 人まで & 36 & 12 \\
\hline 4 人 & 86 & 28.7 \\
\hline 5 人 & 77 & 25.7 \\
\hline 6 人 & 61 & 20.3 \\
\hline 7 人以上 & 40 & 13.3 \\
\hline 合計 & 300 & 100 \\
\hline
\end{tabular}

問 2 年間の平均収入

\begin{tabular}{|r|c|c|}
\hline $40-60$ 万 $\mathrm{Tg}$ & 93 & 31.3 \\
\hline $60-80$ 万 $\mathrm{Tg}$ & 47 & 15.8 \\
\hline $80-100$ 万 $\mathrm{Tg}$ & 49 & 16.5 \\
\hline $100-140$ 万 $\mathrm{Tg}$ & 44 & 14.8 \\
\hline $140-200$ 万 $\mathrm{Tg}$ & 37 & 12.5 \\
\hline 200 万 $\mathrm{Tg}$ 以上 & 27 & 9.1 \\
\hline 合計 & 297 & 100 \\
\hline
\end{tabular}

ンゴル国統計局（NSO 2004）による全国の遊牧 民の家畜所有頭数の分布と比較すると, SHSを所 有する世帯は中間層以上に該当する世帯の割合が 多いことが分かる（図3）.

\section{SHSの導入とその動機}

SHS の購入先 (表8問4) としては, 「10万戸ソー ラーゲル計画」による国からの購入が最も多い $(78 \%)$.「都市の販売店」や「訪問販売注4)」から 購入したケースは合計でも約 $16 \%$ であった. ま た, SHSの使用期間は, それぞれ 1 年以内が $30 \%$, 2 年間が $41 \%, 3$ 年間が $24 \%, 3$ 年以上が $5 \%$ を示 し， 2 年以内の世帯が $71 \%$ であり, SHS の利用経 験が少ないユーザが多いことが分かる.

SHS を導入した動機（表 8問 6) は, 生活の利 便性向上への欲求という意味での「電化製品を利 用したい」 $(53.3 \%)$ が最も多く, 次いで「近隣の 家庭で体験して便利に感じた」(21\%)であった。

SHSを導入する前に使用していた電源について は,「電源を使用してなかった」 $(44 \%)$ が最も多 い(表 8問 7). SHS を導入するまでに発電機, 風 力発電システム, 蓄電池など何らかの電源システ ムを使用したことがあり,電気の便利さを知って いた世帯は合計 $56 \%$ である.

また, 他の電源システムではなくSHSを選んだ 理由としては,「燃料が要らない」(51\%) と「持 ち運びが便利である」(19\%) が多かった（表8問 8).小型ガソリン発電機を使用する遊牧民世帯で は, 燃料の宅配サービス等がないため, 平均的に

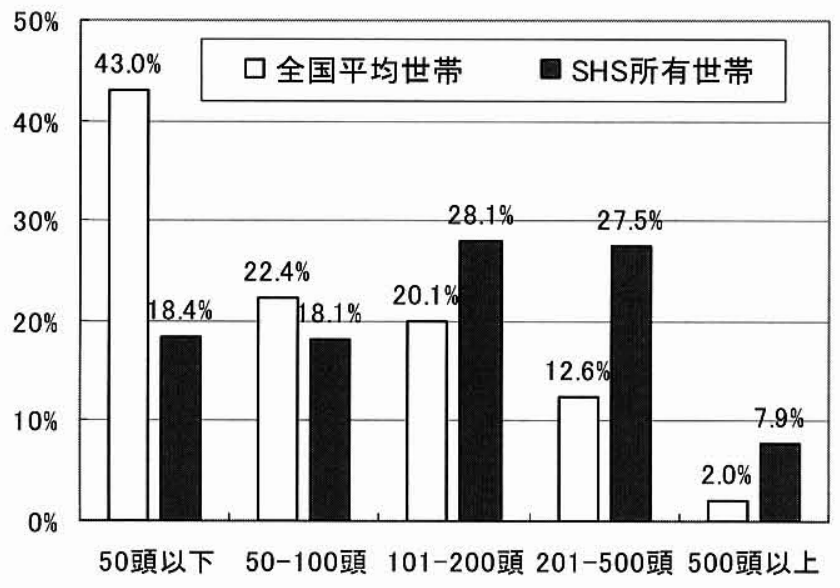

図3 SHS所有世帯と一般世帯の家畜所有頭数の比較 
$60 \mathrm{~km}$ 離れた村落センターからガソリン燃料を定 期的に調達する必要がある。しかし，これには多 額の経費が掛かるため, 小型ガソリン発電機の継 続的利用は困難である.

\section{SHSの維持管理}

SHS の太陽電池モジュールの設置場所（表9問 9)は,「専用ポールに設置している」が最も多かっ た $(71.6 \%)$ 。しかし，住居（ゲル）の上に置いて いる世帯もあった (22.5\%)。このような場合，モ ジュールの裏百密閉された状態となり, 開放状

表8 SHSの導入，その動機について

\begin{tabular}{|c|c|c|}
\hline 選択項目 & 度数 & {$[\%]$} \\
\hline \multicolumn{3}{|l|}{ 問 4 SHS の購入先 } \\
\hline 都市の販売店 & 27 & 8.2 \\
\hline 10 万戸ソーラーゲル計画 & 258 & 77.9 \\
\hline 訪問販売 & 25 & 7.6 \\
\hline その他 & 21 & 6.3 \\
\hline 合計 & 331 & 100 \\
\hline \multicolumn{3}{|l|}{ 問 6 SHS 導入の動機 } \\
\hline 電化製品を利用したい & 184 & 53.3 \\
\hline $\begin{array}{l}\text { 近隣の家庭で体験して便利に感 } \\
\text { じた }\end{array}$ & 72 & 20.9 \\
\hline $\begin{array}{l}10 \text { 万戸ソーラーゲル計画による } \\
\text { 優遇措置を知った }\end{array}$ & 63 & 18.3 \\
\hline 友人に勧められた & 25 & 7.2 \\
\hline その他 & 1 & 0.3 \\
\hline 合計 & 345 & 100 \\
\hline \multicolumn{3}{|c|}{$\begin{array}{l}\text { 問 } 7 \text { SHS を購入する削に電源を使用してい } \\
\text { たかどうか }\end{array}$} \\
\hline 電源はなかった & 128 & 43.8 \\
\hline 小型ガソリン発電機 & 79 & 27.1 \\
\hline 風力発電システム & 20 & 6.8 \\
\hline 蓄電池 & 31 & 10.6 \\
\hline その他 & 34 & 11.6 \\
\hline 合計 & 292 & 100 \\
\hline \multicolumn{3}{|c|}{$\begin{array}{l}\text { 問 } 8 \text { ほかの電源と比べて SHS を選んだ理由 } \\
\text { (複数回答) }\end{array}$} \\
\hline 燃料が要らない & 252 & 51.2 \\
\hline 騒音がなく, 安全 & 45 & 9.1 \\
\hline 持ち運びが便利 & 93 & 18.8 \\
\hline 他に選択肢がなかった & 30 & 6 \\
\hline 環境に優しい・趣味 & 63 & 12.8 \\
\hline 他の理由 & 11 & 2.2 \\
\hline 合計 & 493 & 100 \\
\hline
\end{tabular}

態の設置 (㕀用ポールに設置)よりモジュール温 度が上.昇し出力が低下寸る.また，モジュールの 高温状態はホットスポットや少化の原因となり， 火災の恐れもある。

SHSの故障しやすい部分は充放電装置やブレー カやヒューズなどを含む「コントロールボック ス」(32.2\%) と「蓄電池」(29.7\%) である（表 9 問 11). しかし, 故障回数注5)（問 10）は，1回が 44件, 2 回以上が 23 件であり, 故障頻度は比較的 少ないといえる.これはSHSを購入して 1,2 年 しか経ってない世帯が多いからであると考えられ る.また,これ以外には, ヒアリング調查の結果 から「遊牧で移動して再度 SHS を組み立てる際 に接続ミスによる短絡」が多いことが分かった。

故障したときの対処方法は. (表 9 問 12), 現在 はSHSの修理とサポートを行う業者と修理店が 少ないため, 故障した際には「電気に詳しい知人 に頼む」(54.5\%) が最も多く, 次いで「自分たち で対応する」が多かった (19.4\%).

SHSの保守管理の作業内容としては, 機材の掃

表9 SHSの維持管理について

\begin{tabular}{|c|c|c|}
\hline 選択項目 & 度数 & {$[\%]$} \\
\hline \multicolumn{3}{|c|}{ 問 9 太陽電池の設置場所 } \\
\hline 専用ポール等に設置 & 232 & 71.6 \\
\hline ゲルの上に固定 & 73 & 22.5 \\
\hline その他 & 19 & 5.9 \\
\hline 合計 & 324 & 100 \\
\hline
\end{tabular}

問 11 SHS のどの部分が故障しやすいか

\begin{tabular}{|l|c|c|}
\hline 太陽電池 & 26 & 10.9 \\
\hline 蓄電池 & 71 & 29.7 \\
\hline コントローラ & 77 & 32.2 \\
\hline ケーブル & 21 & 8.8 \\
\hline パネル固定具 & 19 & 7.9 \\
\hline その他 & 25 & 10.5 \\
\hline 合計 & 239 & 100 \\
\hline
\end{tabular}

問 12 故障した場合どのように修理して いるか

\begin{tabular}{|l|c|c|}
\hline 自分達で対応する & 79 & 29.4 \\
\hline 電気に詳しい人に頼む & 147 & 54.6 \\
\hline 購入先・修理店に依頼 & 25 & 9.29 \\
\hline その他 & 18 & 6.69 \\
\hline 合計 & 269 & 100 \\
\hline
\end{tabular}


除, 太陽電池モジュールの固定具等の設置の安全 点検, コントローラや踾電池の電圧やインジケー 夕等の正常動作の確認, さらには開放型の蓄電池 を使用している場合には電解液の補充確認があ る.これらの維持管理についてはSHSの種類や導 入時期によっても異なり，適宜行われていた（七 アリング記録より).

\section{SHS導入の日常生活と農牧業への効果}

SHS導入による日常生活の変化の中で良かった 点（表 10）については,「テレビ放送のニュース や市場情報などを即時に入手している」が最も多 かった $(53.8 \%)$ 。これは, 新聞, 雑誌などの情報 媒体が遊牧民の元に届くのは一週間以上遅れると いう現状があり，SHSの導入により電源が確保で きたことで,テレビを通じて都市地城の住民と格 差なく，様々な情報を即時に得られるようになっ たことを意味する.

次いで多かったのが，「天気予報を詳細に把握 できる」(22.9\%) である.天気予報は遊牧民が放 牧計画を立てる上で重要な情報である.具体的な 例を2つ示すと,大雪や大雨が予想されるの場合 は，放牧せず畜舎や椢に待避させておく. 強風が 予想される場合は，予め風が吹く方向に放牧し， 風が強まったときに追い風によって容易に帰宅す るなどの土夫がなされている.

さらには, SHSにより畜舎に照明の設置が可能 となり,オオカミによる家畜被害の防止対策にも なる. SHS 導入の効果について調查結果では, 情 報入手の環境が改善されたことが挙げられた(表

表10 SHS導入による良かった点(問 13 , 複数回答)

\begin{tabular}{|l|r|r|}
\hline \multicolumn{1}{|c|}{ 選択項目 } & \multicolumn{1}{|c|}{ 度数 } & \multicolumn{1}{c|}{ [\%] } \\
\hline $\begin{array}{l}\text { テレビ放送のニュース・市場 } \\
\text { 情報などを即時に入手してい } \\
\text { る }\end{array}$ & 279 & 53.8 \\
\hline 天気予報を詳細に把握できる & 119 & 22.9 \\
\hline $\begin{array}{l}\text { 映画やドラマを楽しめるよう } \\
\text { にった }\end{array}$ & 75 & 14.5 \\
\hline $\begin{array}{l}\text { 教育番組が見られるようにな } \\
\text { った }\end{array}$ & 32 & 6.2 \\
\hline $\begin{array}{l}\text { テレビ鑑賞を通じて近所との } \\
\text { 交流が樑まった }\end{array}$ & 7 & 1.3 \\
\hline その他 & 6 & 1.2 \\
\hline 合計 & 519 & 100 \\
\hline
\end{tabular}

10)。遊牧業を営む上で, 気象環境と牧草地と家 畜という3つの基本要素に加えて市場と生活状況 の情報を巧みに活用しなけば, 自然災害などに遭 遇する恐れがある. 2000年に大寒波 (ゾド)によ り約 240 万頭の家畜が凍死したという惨事が起 こった（森永由紀・篠田雅人 2003）が.今後, 気 象情報を的確に入手し，被害回避の対策を取れ ば, 大きな被害を未然に防ぐことができると考え られる。

なお, SHSの導入によって悪影響が見られた点 としては,ドルノゴビ県サインシャンド村落 (11 世帯）とヘンティー県ダダル村落 (12世帯)の遊 牧民一の予備調查（ヒアリング調査）において, 「子供達がテレビを見すぎる」という意見が数軒 でみられた程度で，それ以外には「特に無い」と いう意見が多かった。

\section{SHSの欠点と今後の要望}

SHSの欠点（表 11問 15）としては，「価格が高 い」(48.9\%) が最も多く，次いで「利用時間の制 限」(22.7\%) が多かった。「価格が高い」に関し ては,「10万ソーラーゲル計画」により SHSの購 入一の優遇措置 (補助金, 無利子融資) はあるも のの, 年間収入からすると割高感がみられる.

今後の要望を3つのカテゴリー別にみると, 修 理方法に関しては「村落センターに修理店の設 立」(39.1\%) と「ユーザマニュアルの充実化」 (36.8\%) への要望（表 11 問 16）がほぼ同様の割 合で高い.簡単な故障についてはユーザが対応で きるようになりたいため,「ユーザマニュアルの 充実化」が高い割合を示したと考えられる。保 証・品質（表11問 17）に関しては,「保証期間の 長期化」(61.0\%) の割合が高い，その背景には, 「10万ソーラーグル計画」から購入したSHSの保 証期間は 1 年であり，また販売店や商人による訪 問販売では商品が保証されないことがある。ま た，SHS の価格・販売体制・その他（表 11 問 18） に関しては,「SHSの販売価格の值下げ」(46.6\%) が最も多い. 次いで，「SHS と蛍光灯，蓄電池な どが村落内で購入可能に」(28.5\%) と「SHS のサ イズ拡大, 出力増加」(24.9\%) とほぼ同様の割合 を示した。「SHSのサイズ拡大, 出力増加」は, 冷 蔵庫などの消費電力の大きい電化製品も使用した いという要望によるものと考えられる. 
表11 SHSの欠点, 今後の要望 (複数回答)

\begin{tabular}{|c|c|c|}
\hline 選択項目 & 度数 & [\%] \\
\hline \multicolumn{3}{|l|}{ 問 15 SHS の点 } \\
\hline 価格が高い & 153 & 48.9 \\
\hline 利用時間の制限 & 71 & 22.7 \\
\hline 頻繁に故障する & 20 & 6.4 \\
\hline 操作が難しい & 21 & 6.7 \\
\hline $\begin{array}{l}\text { その他（欠点なし, 分か } \\
\text { らない) }\end{array}$ & 48 & 15.4 \\
\hline 合計 & 313 & 100 \\
\hline \multicolumn{3}{|c|}{ 問 16 修理体制・方法について } \\
\hline $\begin{array}{l}\text { 村落センターに修理店の } \\
\text { 設立 }\end{array}$ & 136 & 39.1 \\
\hline $\begin{array}{l}\text { ユーザマニュアルの充実 } \\
\text { 化 }\end{array}$ & 128 & 36.8 \\
\hline 修理派遣員の巡回 & 84 & 24.1 \\
\hline 合計 & 348 & 100 \\
\hline \multicolumn{3}{|c|}{ 問 17 長期保証・品質について } \\
\hline 保証期間の長期化 & 159 & 61 \\
\hline 周辺機器の品質向上 & 87 & 33.2 \\
\hline $\begin{array}{l}\text { その他(特にない, 有料 } \\
\text { 保証の延長) }\end{array}$ & 15 & 5.8 \\
\hline 合計 & 261 & 100 \\
\hline \multicolumn{3}{|c|}{$\begin{array}{l}\text { 問 } 18 \text { SHS の価格・販売体制・他につ } \\
\text { いて }\end{array}$} \\
\hline SHS の販売価格の值下げ & 79 & 46.6 \\
\hline $\begin{array}{l}\text { SHS と蛍光灯, 蓄電池な } \\
\text { どが村落内で購入可能に }\end{array}$ & 48 & 28.5 \\
\hline $\begin{array}{l}\text { SHS のサイズ拡大, 出力 } \\
\text { 増加 }\end{array}$ & 42 & 24.9 \\
\hline 合計 & 169 & 100 \\
\hline
\end{tabular}

表12 SHSに対する総合的評価

\begin{tabular}{|l|c|c|}
\hline \multicolumn{1}{|c|}{ 選択項目 } & 度数 & {$[\%]$} \\
\hline \multicolumn{2}{|c|}{ 問 19 SHS に対する満足度 } \\
\hline 満足している & 308 & 89.3 \\
\hline どちらでもない & 29 & 8.4 \\
\hline 満足していない & 8 & 2.3 \\
\hline 合計 & 345 & 100 \\
\hline 問 20 他人へSHS 勧めるかどうか \\
\hline 钊める & 252 & 75.9 \\
\hline どちらでもない & 60 & 18.1 \\
\hline 勧めない & 15 & 4.5 \\
\hline 分からない & 5 & 1.5 \\
\hline 合計 & 332 & 100 \\
\hline
\end{tabular}

\section{総合評価}

SHS を導入したことによる満足度としては， $89 \%$ の世帯が導入して満足している(表12問19). また, 76\%の世帯がSHSを他人に勧める（表 12 問 20）と答えている.これらの結果より, SHSを導 入したことによる遊牧民の総合評価は高い傾向に あるといえる. ただし, SHSを導入して 2 年未満 の世帯が7割以上を占めており，この評価はあく までSHS導入の初期段階のものである.利用年数 が経つにつれて, 表 11 で明らかとなった様々な 欠点や要望を如何に解決するかが, 今後のSHSに 対する評価に影響を及ぼすと考えられる.

\section{SHSの性能ごとに見た遊牧民の生活の実態}

ここでは, 使用しているSHSの性能 (太陽電池 の定格出力 : $62 \mathrm{~W}, 50 \mathrm{~W}, 20 \mathrm{~W})$ 別にみた利用実 態を述べるとともに発電量と消費電力量のバラン スを試算する。

\section{定格出力62Wのケース (世帯A)}

トゥブ県ナライフ村落の 6 人家族の世帯 A で は, 2003年10月から表13に示寸仕様のSHSセッ トを利用している (図4). SHS の導入の動機は, ラジオ番組で「10万ソーラーゲル計画」の内容と その優遇措置 (補助金と 1 年間無利子ローン) を 知ったことであった.この世帯の年収は約 80 万 $\mathrm{Tg}$ (約 7 万 5 千円) であり, 所有する家畜頭数は 120 頭である. 購入したSHSセットの価格は37万 $\mathrm{Tg}$ (約 3 万 5 千円) であり, 価格の $50 \%$ は補助金 を受けて残額(18万 $5 千 \mathrm{Tg}$ ) は 1 年間の無利子ロー

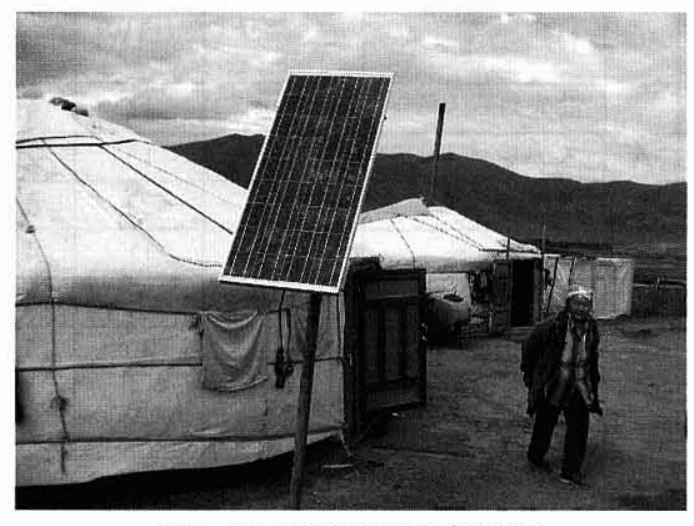

図4 SHSの設置状況 (世帯A) 
ンで支払った. SHSの導入により,「照明とテレビ が使えるようになったので大変満足している」と のことであった.

世帯 $\mathrm{A}$ は, 蛍光灯, ステレオ, テレビを使用し (表 14, 図 5), 平均的に夏季は $184 \mathrm{Wh} /$ 日, 冬季は $169 \mathrm{Wh} /$ 日の電力消費をしている. そこで, 日射量 が少ない冬季の発電量を推定し, 電力の需給バラ ンスについて検討した.気象観測所(ナライフ)の 12 月の平均水平面日射量は $1.1 \mathrm{kWh} / \mathrm{m}^{2} /$ 日であり, 傾斜角 $60^{\circ}$ に対する推定日射量は $3.2 \mathrm{kWh} / \mathrm{m}^{2} /$ 日で ある(注6). 従って, 太陽電池モジュール $62 \mathrm{~W}$ から $198 \mathrm{Wh} /$ 日の発電量を期待できるため, 消費電力量 $169 \mathrm{Wh} /$ 日に対して需給バランスが取れているとい える.

表13 刘象世帯のSHSの仕様

\begin{tabular}{|l|l|l|l|}
\hline $\begin{array}{c}\text { 世龷 } \\
\text { 帯 }\end{array}$ & SHS の要素 & 製造国, メーカ & 定格出力 \\
\hline \multirow{4}{*}{$\mathrm{A}$} & 太陽電池 & 日本, Sharp & $62 \mathrm{~W}$ \\
\cline { 2 - 4 } & 充放電装置 & タイ, Leonics & $12 \mathrm{~V}, 6 / 10 \mathrm{~A}$ \\
\cline { 2 - 4 } & 蓄電池 & 中国, Toyo & $12 \mathrm{~V}, 70 \mathrm{Ah}$ \\
\hline \multirow{4}{*}{$\mathrm{B}$} & 太陽電池 & 中国, Sunpower & $50 \mathrm{~W}$ \\
\cline { 2 - 4 } & 充放電装置 & 中国, Steca & $12 \mathrm{~V}, 6 / 10 \mathrm{~A}$ \\
\cline { 2 - 4 } & 蓄電池 & 中国, Toyo & $12 \mathrm{~V}, 65 \mathrm{Ah}$ \\
\hline \multirow{3}{*}{$\mathrm{C}$} & 太陽電池 & 中国, Suntech & $20 \mathrm{~W}$ \\
\cline { 2 - 4 } & 充放電装置 & 中国, Steca & $12 \mathrm{~V}, 6 / 10 \mathrm{~A}$ \\
\cline { 2 - 4 } & 蓄電池 & 中国, Toyo & $12 \mathrm{~V}, 38 \mathrm{Ah}$ \\
\hline
\end{tabular}

\section{定格出力50Wのケース(世帯B)}

ドルノゴビ県サインシャンド村落の家族 5 人の 世帯Bでは, 表13に示す仕様のSHSセットを2004 年10月から使用している. SHSの導入の動機は, 「10万ソーラーグル計画」の優遇措置を知ったこ とであった．年間収入は約 100 万 $\mathrm{Tg}$ (約 9 万 $4 千$ 円）であり, 所有家畜頭数は約 250 頭であった. この世帯では, 中継アンテナから離れているた め, テレビ放送は受信できないが, テレビゲーム 機能が付いたビデオCD・DVDの再生機を使用し ていた. 世帯主は,「SHSは故障したがこと無い, 性能に対して大変満足している, 他人に勧めた い, 要望はテレビ放送の受信可能範囲の拡張であ る」とコメントした.

この世帯における平均的な消費電力を計算する と, 夏季 $246 \mathrm{Wh} /$ 日, 冬季 $193 \mathrm{Wh} /$ 日となった (表

表14 対象世带の電化製品の仕様と平均使用時閒

\begin{tabular}{|c|c|c|c|c|c|}
\hline \multirow{2}{*}{$\begin{array}{l}\text { 世 } \\
\text { 帯 }\end{array}$} & \multirow[t]{2}{*}{ 電化製品 } & \multirow[t]{2}{*}{ 製造国 } & \multirow{2}{*}{$\begin{array}{l}\text { 消費電 } \\
\text { 力 [W] }\end{array}$} & \multicolumn{2}{|c|}{$\begin{array}{l}\text { 平均使用 } \\
\text { 時間 [h] }\end{array}$} \\
\hline & & & & 夏 & 冬 \\
\hline \multirow{3}{*}{ A } & 蛍光灯 & タイ & 11 & 4 & 6 \\
\hline & ステレオ & 中国 & 15 & 2 & 1 \\
\hline & 白黒テレビ & 中国 & 22 & 5 & 4 \\
\hline \multirow{4}{*}{ B } & 蛍光灯 & 中国 & 11 & 4 & 6 \\
\hline & ラジオ & ロシア & 1 & 2 & 2 \\
\hline & 白黒テレビ & 中国 & 30 & 5 & 2.5 \\
\hline & $\begin{array}{l}\text { ビデオ CD プ } \\
\text { レーヤー }\end{array}$ & 中国 & 20 & 5 & 2.5 \\
\hline \multirow{2}{*}{$\mathrm{C}$} & 蛍光灯 & 中国 & 11 & 1 & 4 \\
\hline & 白黒テレビ & 中国 & 30 & 2 & 0.5 \\
\hline
\end{tabular}

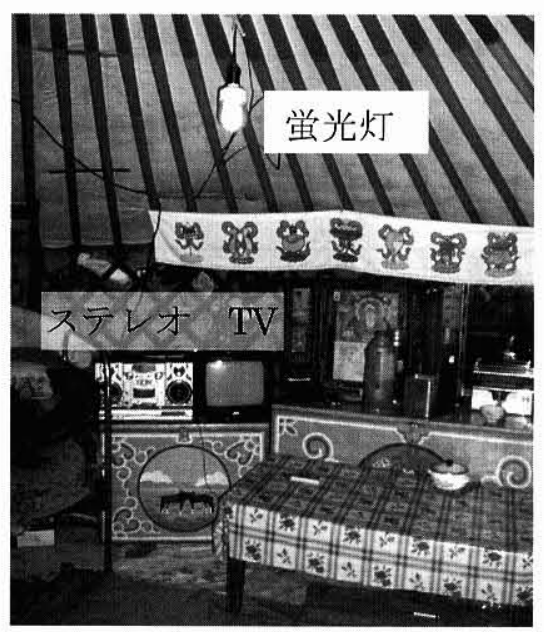

図5 ゲル内の電化製品 (世帯 $\mathrm{A}$ ) 
14）。射量が少ない冬季や消費電力が多い時は 太陽電池モジュールを太陽に向けて置き直す工夫 をしているという.

著者ら（2004）は, サインシャンド市において 太陽電池の暴露試験を行っている.モジュールの 傾斜角を $45^{\circ}$ に設置した，この世帯と同タイプ (多結晶)の太陽電池は夏季には約6[h/日]等価稼 働時間注 7), 冬季には約 4[h/ 日]等価稼働時間の 発電することが示された. これにより, $50 \mathrm{~W}$ 太陽 電池モジュールの発電量は夏季に約 $300 \mathrm{Wh} /$ 日, 冬 季に約 $200 \mathrm{Wh}$ /日と推定され, 発電量と消費電力量 は平均的にバランスが取れているといえる.

\section{定格出力20Wのケース (世帯C)}

ヘンティー県ダダル村落, 家族4人の世帯Cは, 定格出力が 20 W の SHS (表 13) を2003年11月か ら使用している. SHSの導入動機はこれまで使用 していたローソクではなく,電気でもっと明るい 照明を点けたいということであった. 購入先は首 都ウラーンバートル市内の販売店で, 購入価格が 約 15 万 $\mathrm{Tg}$ (約 1 万 4 千円) であった. 所有する家 畜頭数は約 100 頭, 平均年収は約 60 万 $\mathrm{Tg}$ (約 5 万 6千円）である.

ダダル気象観測所の 12 月の平均水平面日射量は $1.3 \mathrm{kWh} / \mathrm{m}^{2} /$ 日であり, 傾斜角 $60^{\circ}$ に対する推定日 射量は $3.6 \mathrm{kWh} / \mathrm{m}^{2} /$ 日である注6). 従って, 太陽電池

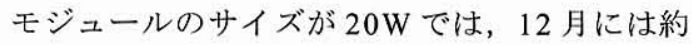
$72 \mathrm{Wh} /$ 日の発電量しか期待できない. そのため, 照 明だけでも使用時間が最大で6時間, テレビだけ では 2 時間程度と限定される. 実際の電化製品の 利用時間から見ても世帯A，BのSHS と比べてか なり少ないことが分かる（表 14）.

しかしながら,「とにかく,照明が日常的に使用 できることが大事なので, その点においては現在 のSHSに満足している」という意見が世帯主から 聞かれた. 将来は大きいサイズのSHSを購入する 考えがある。

\section{SHS未利用者へのアンケート調査結果}

\section{アンケート回答者の属性}

家族数は 4 人または 5 人家族の割合が多く（表 15 問 1), SHS 利用世帯の家族数の分布 (表 7 問 1) とほぼ同じであった，家畜頭数（図6）と平均年
収の分布 (表 15問 2) では, SHS の未利用世帯は SHSを利用する世帯より,いずれも少ないという 傾向がみられた.

\section{SHSに対する認識程度と今後の導入可能性}

SHSについて, 約半数の世帯が名前のみではな く,性能等もよく知っていることが明らかになっ た (表 16 問 4). 今後, 電源システムを購入する 予定がある世帯は $55 \%$, 購入したいが経済的に困 難という世帯が $31 \%$, 電源は特に要らないという 世帯は $14 \%$ であった（表 16 問5)。また，導入し たい電源の種類ではSHSが $72 \%$ と大半を示して

表15SHS未利用の回答者の属性

\begin{tabular}{|c|c|c|}
\hline 選択項目 & 度数 & {$[\%]$} \\
\hline \multicolumn{3}{|l|}{ 問 1 家族数 } \\
\hline 3 人まで & 10 & 20 \\
\hline 4 人 & 14 & 28 \\
\hline 5 人 & 16 & 32 \\
\hline 6 人以上 & 10 & 20 \\
\hline 合計 & 50 & 100 \\
\hline \multicolumn{3}{|c|}{ 問 2 年間の平均収入 } \\
\hline $40-60$ 万 $\mathrm{Tg}$ & 15 & 34.1 \\
\hline $60-80$ 万 $\mathrm{Tg}$ & 14 & 31.8 \\
\hline $80-100$ 万 $\mathrm{Tg}$ & 9 & 20.5 \\
\hline $100-140$ 万 $\mathrm{Tg}$ & 4 & 9.1 \\
\hline $140-200$ 万 $\mathrm{Tg}$ & 2 & 4.5 \\
\hline 合計 & 44 & 100 \\
\hline
\end{tabular}

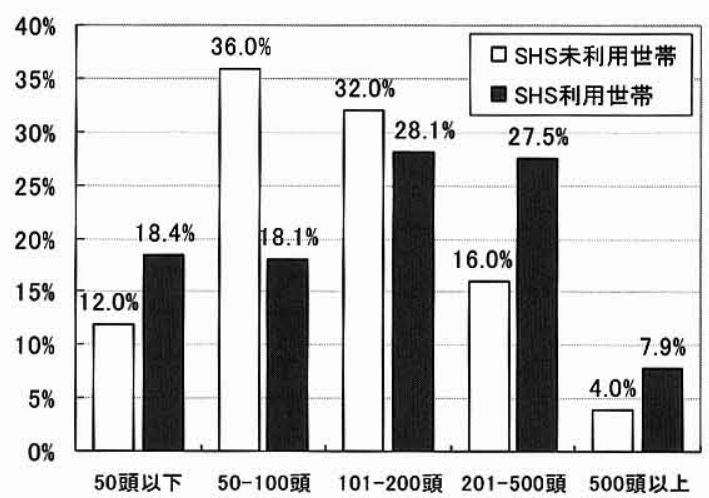

図6 SHS利用と未利用世帯の家畜所有頭数の比較 
いる（表16問6)。従って，認識程度の結果（表 16 問4）も踏まえると，今後 SHS が普及するポテン シャルは高いと考えられる。

\section{考察}

SHSの導入に伴い, 2000 年に $10.7 \%$ であった遊 牧民の電化率が 2005 年 3 月の推定では約 $29 \%$ とな り 5 年間で約 3 倍に向上した。 今後もSHS $の$ 導入 件数が増加すると予想される。ここでは, 本研究 の調査結果を踏まえて, 今後のSHSの普及定着の 課題と農牧業の生産性向上におけるSHSの活用の 可能性について検討する.

\section{「10万戸ソーラーゲル計画」による優遇措置の見} 直し

「10万戸ソーラーグル計画」は遊牧民の SHS 購 入に際して, 当初, 無利子の 1 年間ローンの実施, さらにその後 $50 \%$ の補助金と利子 $0 \%$ の 1 年間ロー ンを実施してきた。こうした優遇措置によって, 2005 年までに約 3 万 2 千世帯の遊牧民にSHSが導 入された注2).今回のアンケート調査において回 答者の $78 \%$ が 10 万戸ソーラーゲル計画の優遇措 置を利用した (表 8 問4) ことからも，優遇措置は SHSの普及が促進される要因になったと考えられ

表16 未利用者のSHSに対する認識程度と導入可能性

\begin{tabular}{|c|c|c|}
\hline 選択項目 & 度数 & [\%] \\
\hline \multicolumn{3}{|l|}{ 問 4 SHS に対する認識程度 } \\
\hline 名前のみ知っている & 25 & 52.1 \\
\hline 性能等も良く知っている & 22 & 45.8 \\
\hline まったく知らない & 1 & 2.1 \\
\hline 合計 & 48 & 100 \\
\hline \multicolumn{3}{|c|}{ 問 6 電源システムの購入の意思 } \\
\hline 購入予定がある & 27 & 55.1 \\
\hline 購入したいが, 経済的に困難 & 15 & 30.6 \\
\hline 電源は不要 & 7 & 14.3 \\
\hline 合計 & 49 & 100 \\
\hline \multicolumn{3}{|l|}{ —問 7 導入したい電源の種類 } \\
\hline 小型発電機 & 3 & 6.5 \\
\hline 風力発電システム & 1 & 2.2 \\
\hline SHS & 33 & 71.7 \\
\hline 蓄電池 & 4 & 8.7 \\
\hline その他 & 5 & 10.9 \\
\hline 合計 & 46 & 100 \\
\hline
\end{tabular}

る.しかし, 表8問6のSHS導入の動機について, 「電化製品を利用したい」 $(53.3 \%)$ と「近隣の蒙 庭で体験して便利に感じた」(20.9\%) が合わせて $74.2 \%$ を示す.このように生活の利便性の向上へ の要望や満足が,「10万ソーラゲル計画による優 遇措置を知った」(18.3\%) を上回ることから，今 後も優遇措置に関係なくSHS を導入したいとい う世帯が増える可能性はある.また, モンゴル国 の今後の財政状況を考慮すると, 今後持続的な SHSの普及定着のためには, 現在の「10万戸ソー ラーゲル計画」による補助金に依存した形態では なく,市場原理の中でSHSを販売していくことが 望ましい.このため, 例えば現行の補助金の割合 を $30 \% ， 15 \%$ などと段階的に引き下げる代わり に, ローンの期間を 1.5 年, 2 年と長期化するなど の対策が必要であると考えられる.

\section{SHSのサポート体制の整備}

SHSの欠点として「利用時間の制限」(22.7\%) があげられている（表11問 15).SHS は，雨など の悪天候が続き，蓄電池への充電が不足した場 合，充放電制御装置の過放電の防止機能によっ て, 電力利用が制限されることがある.SHSのこ のような特性を認識した上で, 天気予報から日照 時間を把握して電力消費を節約するなどの電力需 要の管理（DSM=Demand Side Management）を行 う必要がある. そのためには, SHS導入時のユー ザトレーニング（利用者研修）が不可欠である. また，回答結果から，SHS利用者は保証期間の長 期化と修理店の設立を要望していた. 修理専門店 のネットワーク構築, 技術者などの人材育成, さ らには簡単なトラブルなどに対して SHS 利用者 自らが対処できるためにSHSの利用・管理方法に 関するユーザマニュアルと参考書の充実が必要で ある.こうしたことから, SHSの総合的なサポー 卜体制の構築が課題と考えられる.

\section{農牧業情報の活用環境の整備}

「はじめに」で述べたように社会的・自然的要 因による様々な問題を克服し,農牧業の生産性を 向上させていくためには,牧畜の伝統的な技法に 加えて科学的手法と最新技術を積極的に用いる必 要がある.特に, 農牧業情報の活用環境の整備が 
不可欠である. 具体的には，遊牧民を対象とした TVやラジオ放送の番組内容を充実させるなどし て, 遊牧民が農牧業の環境負荷, 牧草地荒廃のメ カニズムや要因等について理解を深めること,ま た, 牧草地の植物分布・育成状況などの解析情報 を遊牧民に定期的に提供する情報支援システムが 必要である.さらには, GPSや通信機器を用いて 家音の位置確認や放牧経路の記録・蓄積によって 牧草地の高度管理が可能となるであるう。

SHSは性能上, 動力や熱利用などの高出力 $(1 \mathrm{~kW}$ 以上）を供給することはできず農牧業の生産性向 上に值接的に寄与できる可能性は低い。しかし， その中でSHSが上述した農牧業の情報支援システ ムや通信機器の電源として活用すれば, 遊牧民の 生活水準のみならず農牧業生産性の向上に寄与で きる.

\section{まとめ}

本研究では対面式及びアンケート票調查によ り, SHSを利用している遊牧民の利用実態と SHS 未利用者の認識を明らかにし，今後の課題を整理 した. 本研究より明らかとなった, 主な知見を以 下に示す.

1）SHS を導入することによって照明とテレビを 使用できるようになったことに対して, SHS利 用者は高い満足感 $(89 \%)$ を得ていた。また, SHSは小型かつ軽量であり，また燃料を必要と しないため,移動を繰り返す遊牧民のライフス タイルに適合する技術であることが示された。

2) 遊牧民の平均年収に比べて, SHSの販売価格は 高価である.このため, 市場を介しての普及が 進んでおらず, SHS を導入した世帯の 78\%が 「10万ソーラーゲル計画」による補助金と無利 子ローンを利用して購入していた.

3）SHSは2003年から本格的にモンゴル国内で導 入されたため, 使用期間は2年以内の世帯が多 く, 現時点では故障発生回数は少なかった.し かし，現在の課題は，SHSの保証期間は 1 年以 内と短いこと, 修理店または技術者が近くの村 落センターや県都にいないことである.

4) SHS未利用者に対する調査から, SHSに対する 認識度が高く $(98 \%)$, SHSを購入予定があると いう回答者が多い $(72 \%)$ ことが分かった。
5）SHSの普及定着及びそれによる遊牧民の農 牧業の生産性向上のための課題として, 书 場原理に向けた優遇措置の見直し, サポー 卜体制の整備, 電化率の更なる改善と共に 農牧業情報の活用環境の整備が必要である と考えられる。

注

注 1 ) S H S の特徵は, 太陽電池モジュール, 蓄電 池, 充放電装置, ケーブル, 固定具から構成 されたシンプルなシステムであり(図1)，設 置が容易であるとともに軽量(総重量：30〜 $50 \mathrm{~kg}$ )である. 日中は太陽電池で発電した電 力を蓄電池に貯めておき, 必要に応じてその 電力を供給する，駆動部分がないため騒音は なく, 他の電源システムと比べて長寿命で保 守管理が比較的容易である。 その反面で, 初 期投資コストが高価であり，日射量の変動 (天候と時間帯)によって発電量が制限される という久点がある。

注2) 2005 年 3 月までの 10 万戸ソーラーゲル計画に よる導入量，モンゴル国燃料・エネルギー 省, 再生.可能エネルギー課, 専門家一の聞き 取り調查。

注3）モンゴル国の通貨単位はトゥグルク $\mathrm{Tg}$ であ り，2005年 7 月に 1 円 $=10.68 \mathrm{Tg}, 2003$ 年には 1 円 $=10.11 \mathrm{Tg}$ であった. Bank of Mongolia, <http:/ /www.mongolbank.mn/rates.asp>, 2005年.10月 12 日参照。

注4) 商人が生活必需品などを販売するために各遊 牧民世帯を訪問しており，その際にSHS も販 売している。

注 5 ) 質問 10 と14の回答を表に示さず，文章で表現 している.

注6)モンゴル国気象水文研究所 (Institute of Meteorology and Hydrology of Mongolia)の各気 象観測所の平均水平面日射量データに基づい た傾斜面推定值, <http://www.env.pmis.gov.mn/ Meteoins >, 2005年10月12日参照.

注7) 発電の電力積算量を定格出力で稼働する時間 で示すパラメータである。

\section{引用文献}

アジヤバトアマルバヤル・黒川浩助(2005) モン ゴルにおける独立小型太陽光発電システム実 証研究のデータ解析¥システム評価, 太陽エ 
ネルギー, 168 Vol.31 No.4, 83-88pp.

Amarbayar, A. and Kosuke Kurokawa, et al. (2004)

Evaluation of Solar Energy Potential and PV Module Performance in the Gobi Desert of Mongolia, WREC8, Denver, Colorado, Aug. 2004.

ADB (2002) Mongolia's Environment Implications for ADB's Operations, East and Central Asia Department of Asian Development Bank, PSNo.090602, ISBN 971-561-468-x.

Enebish, N. (2000) National Photovoltaic Program "100,000 Solar House (GER) in Mongolia", 28th IEEE Photovoltaic Specialists Conference, September 15-22, 2000.

Erdenesaikhan, N. (2002) Time-series satellite data analysis for assessment of vegetation cover of Mongolia, ESRI's 22nd Annual User Conference.

本多嘉明 (1999) 衛星観測による植物生産量推定手: 法の開発, 戦略的基礎研究推進事業, 地球変 動のメカニズム, 平成10年度研究年. 報, JST資 料番号J1529AA, 884-888pp.

本多嘉明 (1999) 人工衛星のデータから植物生産量 を調べる手法を開発，<http://www.jst.go.jp/ kisoken/seika/zensen/04honda/>, 2005年10月18日 参照.

Jargal, G. and Y.Otgonbold, et al. (2004) Study Report "Bringing herders' assets into full economic and productive use”, UNDP/SIDA, Ulaanbaatar, 31-33pp. 森永由紀・篠田雅人 $(2003)$ モンゴルの自然災害ゾ ド, 科学, Vol.73 No.5,2003 年5月, 573 $577 \mathrm{pp}$.

NEDO（1997）太陽光発電システム実用化技術開 発, 携带太陽光発電システム実証研究成果報 告書，新エネルギー産業技術総合開発機構， $<\mathrm{http}$ ://www.tech.nedo.go.jp/Index.htm>, 2005年 10 月 18 日参照.

Nieuwenhout, F.D.J. and Dijk, A.L. van, et al. (2001), Experience with solar home systems in developing countries: a review, Progress in Photovoltaics, Vol.9 (DOI: 10.1002/pip.392) 455-474pp.

Nikolakaki, E.Krontiris (2001) "Problems and Prospects of Autonomous Power Plants with Small Scale Wind Turbines in Isolated Areas, Demonstration Project of Rural Electrification in Mongolia", International Conference Renewable Energies for Islands: Towards 100\% RES Supply, Chania - Crete, Greece, 14-16 June 2001.

NSO:National Statistical Office of Mongolia (2004) Statistical Year Book 2003, 141-147pp.
NSO:National Statistical Office of Mongolia (2004b) Statistical Year Book 1989-2002: "Mongolia in a Market System", 163-165pp.

Robinson, B. (1997) In the Green Desert: Nonformal Distance Education Project for Nomadic Women of the Gobi Desert, Mongolia. UNESCO's Education for All Innovations Series, No.12.

新エネルギー財団 $(2005)$ 住宅用太陽光発電システ 厶施工品質向上に関する調查報告書, 平成 17 年3月。

鈴木由紀夫 (2003) モンゴル国における農牧業の現 状, 科学, Vol.73 No.5,2003年5月, 549$553 \mathrm{pp}$.

Tserendash, S. (2000) Some policy related issues for pasture management, Newsletter No. 6 (38), Mongolian Academy of Sciences, Ulaanbaatar.

受付日 2005 年 11 月 1 日

受理日 2006 年 4 月 10 日

担当部会 情報利用・普及部会 


\title{
Actual Conditions and Problems of Solar Home System -Nomadic Families in Mongolia-
}

\author{
Amarbayar Adiyabat ${ }^{* 1)}$, Masahiro Nakajima ${ }^{2)}$, Kenji Otani ${ }^{33}$ \\ and Kosuke Kurokawa ${ }^{1)}$ \\ 1) Faculty of Engineering, Tokyo University of Agriculture and Technology, Nakamachi 2-24-16, \\ Koganei-shi, Tokyo, 184-8588 Japan \\ 2) Faculty of Agriculture, Tokyo University of Agriculture and Technology, Saiwai-cho 3-5-8, \\ Fuchu, Tokyo, 183-8509 Japan \\ 3) National Institute of Advanced Industrial Science and Technology, AIST Central-2, Umezono 1- \\ 1-1, Tsukuba, 305-8568 Japan
}

\section{Summary}

Here, we present the results of a questionnaire survey regarding Solar Home Systems (SHS) in nomadic families in Mongolia. The present study was performed to clarify user behavior, user satisfaction, problems, needs, and awareness of SHS by non-users. The survey was carried out in 67 nomadic families by the face-toface questionnaire method, and 359 responses were received from nomadic families by the mail questionnaire survey method.

From the results, most users indicated that they were satisfied with their SHS. They appreciated improvement in lighting and the ability to watch TV. It is shown that SHS is appropriate power system for nomadic lifestyle to compare with other type generation systems from the view point of users. The main problem for SHS users was a lack of after-sale service. There is a requirement to establish service chains, review of preferential treatment for the sales and support system based on market principle. In order to improve the productivity growth of nomadics, increasing electrification by SHS and enable a sharing of agricultural information are also required.

\section{Keywords}

Electrification, Solar Home System, Questionnaire Survey, Actual conditions, Nomadic family

\section{* Corresponding Author}

E-mail: amar@cc.tuat.ac.jp 